\title{
Advances in diagnosis of colorectal cancer and pancreatic cancer
}

\section{Postępy diagnostyki raka jelita grubego i raka trzustki}

\author{
Piotr Paweł Wysocki ${ }^{\bowtie}$, Elżbieta Świętochowska, Paweł Kiczmer, Zofia Ostrowska
}

Śląski Uniwersytet Medyczny w Katowicach, Katedra i Zakład Biologii Medycznej i Molekularnej, ul. Jordana 19, 41-808 Zabrze Medical University of Silesia in Katowice, Department of Medical and Molecular Biology

$\triangle$ pp.wysocki@gmail.com

\begin{abstract}
Introduction: Current advanced diagnostic methods enable us to diagnose and differentiate many diseases in their early stages, but early detection of pancreatic cancer and colorectal cancer remains a challenge for today's medicine. Currently sought techniques are those limiting the use of invasive methods and imaging tests, which often do not dispel doubts. In many scientific studies research is driven by two main mechanisms of carcinogenesis - gene mutations and chronic inflammatory disease. Colorectal cancer: For colorectal cancer there is a promising faecal immunochemical test, taking into account the concentration of haemoglobin in the faeces. Another diagnostic aspect of this tumour may be a test for the presence of various combinations of antibodies against antigens associated with the occurrence of cancer, for example: livin, survivin, carbohydrate antigen 19-9, carcino-embryonic antigen, X chromosomelinked inhibitor of apoptosis protein, etc. In view of the mechanism of chronic inflammation of the organ as a cause of cancer,
\end{abstract}

there are interesting studies carried out on arachidonic acid metabolites in the urine of patients with colon cancer.

Pancreatic cancer: In the case of pancreatic cancer research it is conducted on mutations of chromosomes 8q, 9p and $S K A P 2$ gene, and the hypermethylation of genes such as SFRP1, MESTV2, $A P C$. Also noteworthy is the analysis of the concentrations of adipokines like omentin and adiponectin in the blood of patients with tumours or chronic inflammations of organs. Another strategy for the early diagnosis of pancreatic cancer may be a study of miRNAs as an oncogene or suppressor of tumour transformation, for example: miRNA-21 and miRNA-155, which may also allow the differentiation of benign and malignant lesions.

Conclusions: These methods provide new opportunities for the identification of cancers, but a lot of research still has to be carried out before they become the basic tools incorporated in clinical diagnostic panels.

Keywords: pancreas; colon; tumour; mutation; inflammation.

\begin{abstract}
ABSTRAKT
Wstęp: Dostępne zaawansowane metody diagnostyczne pozwalają diagnozować oraz różnicować wiele chorób już we wczesnych ich stadiach, jednak wczesne wykrywanie raka trzustki oraz jelita grubego nadal stanowi wyzwanie dla dzisiejszej medycyny. Obecnie poszukiwane są techniki ograniczające użycie metod inwazyjnych i badań obrazowych, które często nie rozstrzygają wątpliwości. W wielu pracach naukowych kierunek badań narzucają dwa główne mechanizmy karcynogenezy - mutacje genowe oraz przewlekłe zapalenia narządów.

Rak jelita grubego: Dla raka jelita grubego obiecująco prezentują się badania immunochemiczne kału, uwzględniające stężenie hemoglobiny w kale. Inny m aspektem diagnostycznym tego nowotworu mogą być badania nad obecnością różnorodnych kombinacji przeciwciał przeciw antygenom powiązanym z występowaniem raka (np. liwina, surwiwina, antygen węglowodanowy 19-9, antygen karcynoembrionalny, inhibitor apoptozy sprzężony z chromosomem $\mathrm{X}$ itp.). W świetle mechanizmu przewlekłego zapalenia narządu jako przyczyny nowotworu
\end{abstract}

obiecująco zapowiadają się badania nad metabolitami kwasu arachidonowego w moczu chorych z rakiem okrężnicy.

Rak trzustki: W przypadku raka trzustki prowadzone są badania dotyczące mutacji chromosomów 8q i 9p genu SKAP2 oraz hipermetylacji genów takich jak SFRP1, MESTv2, APC. Na uwagę zasługują także analizy stężeń adipokin omentyny i adiponektyny we krwi chorych ze zmianami nowotworowymi i przewlekłymi stanami zapalnymi narządów. Inną strategią we wczesnej diagnostyce raka trzustki mogą być badania nad miRNA jako onkogenem lub supresorem transformacji nowotworowych, np. miRNA-21 i miRNA-155, które dodatkowo być może umożliwią różnicowanie zmian łagodnych od złośliwych.

Wnioski: Omówione metody prezentują najnowsze możliwości technik identyfikacji nowotworów, ale potrzeba jeszcze wielu badań, aby stały się one podstawowymi narzędziami klinicznymi włączonymi w panele diagnostyczne.

Słowa kluczowe: trzustka; jelito grube; nowotwór; mutacja; zapalenie.

\section{INTRODUCTION}

In Poland, pancreatic cancers account for about $3 \%$ of all cancers, giving it $6^{\text {th }}$ place in the structure of mortality among men and $7^{\text {th }}$ among women. Colorectal cancer is in $2^{\text {nd }}$ place in both

sexes in terms of incidence (12.4\% in men, $10.1 \%$ in women) $[1,2]$. It is the most common cancer in Europe. In the world each year there are 1,130,000 diagnosed cases of this cancer, of which 649,000 cases end in the death of the patient [3]. In Poland, 7,379 deaths caused by this disease were reported in 2010 per 
10,072 diagnosed cases. In Poland and other countries, the gold standard in the diagnostics of colorectal cancer is colonoscopy, which provides valuable diagnostic information, but is associated with the risk of complications such as the discomfort of the patient and the possibility of damage of the intestinal mucosa or perforation. In the case of pancreatic tumours, due to difficult access to the organ, diagnostic standards are based primarily on non-invasive imaging techniques such as: computed tomography, magnetic resonance, and positron emission tomography. Unfortunately, when imaging studies do not provide a full range of information on cancer, an endoscopy is performed to retrieve material for histological tests [2]. The invasiveness of the above-mentioned treatments stimulates progress in research which is aimed at reducing the use of endoscopic methods and focusing on changes that can be observed mainly in the blood, faeces or urine. A considerable amount of worldwide research is devoted to identifying the most specific cancer markers. In addition to confirmation of the disease, they will also evaluate the severity of the tumour, and differentiate chronic inflammation of organs from the actual stages of cancer.

\section{ETIOPATHOGENESIS OF COLORECTAL CANCER}

Risk factors can be divided into environmental, genetic and internal. Approximately $95 \%$ of cases of colorectal cancer are adenocarcinomas. The other are squamous, glandularsquamous and undifferentiated types [4]. Most cases of colon cancer arise from polyp adenoma and are much less pedunculated. The relation between the polyp size and cancer was identified - lesions $<1 \mathrm{~cm}$ are linked with $0.5-1 \%$ probability of cancer, and for those longer than $2 \mathrm{~cm}$, the risk increases to $10-50 \%$ [1]. Removal of the lesions may inhibit the process of carcinogenesis, but unfortunately every $3^{\text {rd }}$ case of colorectal cancer arises from adenomas or serrated polyps, which may not be detected during a colonoscopy because of their morphology and location in the proximal colon.

There are 2 major mechanisms responsible for colorectal cancer: the mechanism of gene mutations, and (increasingly considered) the mechanism of chronic inflammation of the organ, which also includes pancreatic cancer. Mutations in $B R A F$ and $R A S$ have an important role in the origin of colon cancer, since they activate the MAPK pathway, which responds to the activation of growth factor receptors, particularly epidermal growth factor receptor. This leads to the uncontrolled growth and survival of colon epithelial cells. The KRAS mutation affects about $40 \%$ of colon cancer cases [5].

The $2^{\text {nd }}$ mechanism is fuelled by the notion that inflammation and carcinogenesis affect each other, which contributes to the development of cancer. This is clearly visible in the case of ulcerative colitis, which in approximately $20 \%$ of patients develops into colon cancer associated with inflammation. Myofibroblasts present in the intestinal crypts contribute to the repair of the affected tissue by producing transforming growth factor $\beta$ (TGF- $\beta$ ), which stimulates fibroblasts. These in turn, in conditions of continuous activation, are able to stimulate growth and tumour progression by specific mechanisms. In addition to the myofibroblast the stroma also contains M2 macrophages that synthesize TGF- $\beta$, as well as many other cytokines that stimulate angiogenesis, and these include: VEGF-A, VEGF-C, tumour necrosis factor $\alpha$, and interleukin-8. In addition to these cytokines, macrophages synthesize and secrete MMP-2, MMP-7, MMP-9 and MMP-12, involved in the degradation of the extracellular matrix by remodelling and angiogenesis [6]. This is a significant fact since it enables the tumour cells to leave the primary tumour site and may result in further metastases. These mechanisms confirmed the role of chronic inflammation in uncontrolled mucosal cell proliferation, which contributes to the development of colorectal cancer, and its risk increases by $0.5-1 \%$ in patients with intestinal disease active for at least 7 years [7].

\section{DIAGNOSIS OF COLORECTAL CANCER}

All over the world studies are undertaken to limit the use of deeply-invasive diagnostics. Diagnostic procedures are becoming increasingly focused on a potential marker for determining its presence in body fluids or faeces. One example is the faecal immunochemical test (FIT), the purpose of which is to detect haemoglobin, and thus the blood contained in the faeces, which equally occurs as a symptom of cancer on the left and right sides of the colon. This is one type of screening. Cubiella et al. [8] in their study used the faecal immunochemical test with the accepted cut-off $\mathrm{Hb} \geq 100 \mathrm{ng} / \mathrm{mL}$ and compared the sensitivity of benchmarks set by National Institute for Health and Care Excellence (NICE) and Scottish Intercollegiate Guidelines Network (SIGN). Both criteria by NICE and SIGN compared with the FIT are much more complex and dependent on, among others, the patient's age, family burden, persistent rectal bleeding, and diarrhoea or unexplained anaemia associated with iron deficiency. It turned out that a positive result of the FIT standard $\mathrm{Hb} \geq 100 \mathrm{ng} / \mathrm{mL}$ for the location of the lesion in the anus was achieved in 26 out of 30 patients. For the vicinity of the distal colon a positive result was obtained in 40 out of 44 patients, and for the area of the proximal colon in 19 out of 23. The comparison of results with the criteria of NICE and SIGN revealed that FIT ( $\mathrm{Hb} \geq 100 \mathrm{ng} / \mathrm{mL}$ ) has improved sensitivity in the diagnosis of colorectal cancer compared with the standards of NICE and SIGN. It should be noted that the study of FIT could have a reduced sensitivity in the case of right-side colorectal cancer. The reason for this may be that the changes on the right side of the colon are less bleeding, and there is a limited ability to detect degraded haemoglobin in this test [9].

Iovanoescu et al. [10] in their study used a sigmoidoscopy and FIT cut-off point of $\geq 20 \mathrm{mg} \mathrm{Hb} / \mathrm{g}$. The results showed that the combination of these 2 methods increased the sensitivity of the test by $10-30 \%$ compared to the survey based on sigmoidoscopy. An important feature of this study is the reduced range of the performed endoscopy, which in the case of sigmoidoscopy involves the rectum, sigmoideum, and a part of the descending colon. Compared with colonoscopy, this treatment 
is more comfortable for the patient. However, a disadvantage of this method is the lack of an accurate diagnosis of cancer of the transverse and right colon.

Another trend in the diagnosis of colorectal cancer is focused on antibodies against antigens associated with cancer, e.g. survivin, livin, carcino-embryonic antigen (CEA), carbohydrate antigen 19-9 (CA 19-9), p53. Hosono et al. [11] investigated the presence of antibodies and antibody combination coexistence depending on the stage of the tumour. For stage I, $60 \%$ of patients $(n=20)$ had antibodies against survivin and $\mathrm{p} 53$. For stage III, $54.9 \%$ of patients $(n=51)$ had antibodies against CEA and survivin, and $84.8 \%$ of patients $(\mathrm{n}=33)$ with stage VI had antibodies against CEA and survivin, as well as against the $\mathrm{X}$ chromosome-linked inhibitor of apoptosis protein and CEA protein. Studies also suggest that antibodies against survivin and p53 can be used to detect cancer at its early stages.

A different course in the process of diagnosis may be the determination of the marker which is the hypermethylated tumour suppressor gene. An example would be abnormal vimentin gene hypermethylation (mVIM), which has been identified in faeces. However, the processing of genetic material from the faeces causes a high loss of nucleic acids, and therefore isolating WVIM from the urine of patients with adenomas and carcinomas of the colon has become a standard procedure. This is another step in the implementation of new screening tests which exclude the use of endoscopic methods [12].

Urine has also been the object of interest in the context of detecting arachidonic acid metabolites, namely prostaglandin $\mathrm{E} 2$, which is involved in inflammatory reactions. Cyclooxygenase 2 (COX-2) is overproduced in adenomas and malignant tumours, resulting in increased activity of the 15-hydroxyprostaglandin dehydrogenase enzyme. Inhibitors are sought that would block the synthesis at the stage of this enzyme. Elevated prostaglandin $\mathrm{E}_{2}$ can be determined in urine because of dehydrogenase activity. Non-steroidal anti-inflammatory drugs decrease the activity of COX-2, and thus the production of prostaglandins $\mathrm{E}_{2}$. The prophylactic use of aspirin reduces the risk of colon cancer by as much as $40-50 \%$ [3]. Polish prevention guidelines provide a dose of aspirin of $300 \mathrm{mg} / \mathrm{d}$. It should be noted that the inhibition of COX-2 may disturb the regeneration of mucosal damage, which can further exacerbate the condition of a bowel disease [13].

\section{ETIOPATHOGENESIS OF PANCREATIC CANCER}

Risk factors for the development of pancreatic cancer include age (the majority of cases are associated with 70-80-year-olds), smoking, diabetes and chronic inflammation, a diet rich in animal fats, and occupational factors (carcinogens) [14]. Increased risk of pancreatic cancer is also associated with a genetic burden, e.g., hereditary chronic pancreatitis, mutations in BRCA1 and $B R C A 2$, and others. The risk of individuals with a family history of disease is 18 times higher if cancer was diagnosed in a first line relative [2]. Approximately $85 \%$ of cases are ductal adenocarcinoma.

\section{DIAGNOSIS OF PANCREATIC CANCER}

Pancreatic cancer does not produce any characteristic symptoms for a long time. The lack of disturbing symptoms causes tumour growth, which then metastasizes to local vessels and lymph nodes. This means that only $15-20 \%$ of patients qualify for surgery which consists in resection of the pancreas [15]. Therefore, a diagnostic method for the detection of the early stages of pancreatic cancer is much needed.

Tumour marker CA 19-9 is the most commonly assayed marker for pancreatic cancer. However, $5-10 \%$ of patients have a negative Lewis phenotype - Le ( $\alpha-\beta-)$, manifested by the absence of fucosyltransferase, and thus have no CA 19-9. Subjects with this phenotype will have a false negative result. A false positive result may occur in $10-60 \%$ of patients with jaundice [16]. For this reason, other more sensitive markers of pancreatic cancer should be tested for. Pancreatic juice sampled during endoscopy can be tested in order to search for mutant alleles using the SafeSeqS (Safe Sequencing System) technique. Kinde et al. detected mutations of KARS in $85 \%$ of patients with pancreatic cancer. This method, however, does not allow for the detection of early neoplastic lesions [17]. Material in the search for genetic mutations specific for this cancer may be cyst fluid. Mutations in GNAS and/or KRAS were detected in $96 \%(\mathrm{n}=132)$ of patients with intraductal papillary mucinous neoplasms of the pancreas [18].

Dranka-Bojarowska et al. drew attention to the adipose tissue and its ability to produce hormones. The concentration of leptin and adiponectin, which are synthesized in adipocytes and CA 19-9 in the serum, was measured in three groups. One of these was a group of patients with pancreatic cancer in which, irrespective of the body fat, the level of adiponectin was significantly higher than in controls and patients with chronic pancreatitis. In light of these studies, adiponectin, which is an anti-inflammatory adipokine, may be a potential marker in the diagnosis of pancreatic cancer [19]. Another adipokine, omentin, has also been recognized as a potential marker of pancreatic cancer and colon cancer. Research confirms the increase in the concentration of omentin in patients with tumour lesions. However, the role of elevated levels of adipokine has not been clearly explained. Some authors suggest that omentin is a part of the body's defence against cancer cells, while others suppose that it may stimulate neoplastic processes [20]. Karabulut et al. also point out that the concentration of omentin grows depending on the size of the tumour, and factors such as obesity and body mass index have no impact [21].

Harada et al. [22] examined mutations in cancer tissues, mainly chromosome $8 \mathrm{q}$ and $9 \mathrm{p}$ in $96 \%(\mathrm{n}=27)$ and $78 \%(\mathrm{n}=27)$ of patients. Further analysis also revealed mutations in the SKAP2 gene. SKAP2 overexpression was detected at all stages of cancer, and may affect the G1 phase of the cell cycle. Overexpression of the mRNA HIF1a factor and TRL 4 was correlated with reduced tumour size and patient survival of 8 and 7 months [23].

There are interesting studies on hypermethylated gene promoters, which are released by tumour cells into the blood. In studies by Henriksen et al., patients with pancreatic cancer 
had a significantly higher mean level of free DNA, the same as in chronic and acute pancreatitis. Research indicates that in cancer patients hypermethylation most frequently concerns genes: APC, MESTV2, SFRP1 or SFRP2, which allows for the development of a diagnostic panel for pancreatic cancer [24]. Other studies indicate the possibility of extending the panel of genes. Promoter hypermethylation of the p16 gene was detected in the serum of $16-30 \%$ of the patients with pancreatic cancer. It was also observed in other cancers, which could indicate a significant role of $\mathrm{p} 16$ in the process of carcinogenesis. More specific for pancreatic cancer was the BNC1 gene, although its hypermethylation also occurs in the case of lung, breast, kidney, prostate and colon cancer, as well as in the lymphocytes of patients with chronic lymphocytic leukaemia [25].

A promising strategy for the early detection of pancreatic cancer may be the study of non-coding RNA (ncRNA). Genes encoding proteins represent $2 \%$ of the human genome, which for many years allowed researchers to think that the rest of the transcribed genetic information does not indicate any important aspects. For several years, along with research on ncRNA, this view has become less important. Researchers are particularly focused on miRNA, which can act as an oncogene or tumour suppressor, depending on absence or overexpression [26]. The level of miRNA-21 and miRNA-155, which differentiate benign from malignant lesions, can be determined after biopsy, using PCR and in situ hybridization [27]. Ma et al. confirm in their studies that the loss of the miRNA-21 allele reduces the process of carcinogenesis [28]. What is more, miRNA-21 interacts with miRNA-23a and miRNA-27, and inhibition of these three alleles was found to reduce the proliferation of tumour cells in a murine model. High levels of the three miRNAs were also associated with shorter survival in hereditary breast and ovarian cancers. Studies by Nagao et al. also confirmed the elevated expression of miRNA-21 in 75\% of cases of pancreatic ductal adenocarcinoma [29]. Liu et al. [30] indicate miRNA-16 and miRNA-196a as markers for detecting pancreatic cancer. They also point to the possibility of combining this strategy with the classical determination of CA 19-9, the concentration of which is dependent on the size of the tumour.

\section{CONCLUSIONS}

Pancreatic cancer and colorectal cancer pose serious diagnostic problems, as indicated by the statistics of the early detection of these diseases. More accurate methods allow diagnosis based on chemical changes in the body fluids and mutations of the genome. The researchers emphasize that innovative methods of mutation detection will become the primary diagnostic tool for doctors in the near future, which is clearly seen in the case of miRNAs in pancreatic cancer. The development of sensitive methods for the diagnosis of colorectal cancer will reduce colonoscopy use as a basis for the detection of morphological changes in the large intestine. Particularly noteworthy are studies on FIT, which is gaining fame among the screening tests. In addition to FIT, investigators observe changes in blood by detecting specific antibodies against proteins associated with cancer, and biochemical anomalies in urine indicating metabolic products related to inflammation, suggesting the relationship between inflammation and carcinogenesis. Attention should also be drawn to adipose tissue and hormones produced by it, whose levels may provide valuable information in the diagnosis of pancreatic cancer and colon cancer. Each of these methods opens up new possibilities for identifying cancerous changes, but there is still much research to be carried out before these techniques become basic elements of the diagnostic panel.

\section{REFERENCES}

1. Herman R, Reguła J, Pałucki J, Polkowski W, Potemski P. Rak okrężnicy. In: Potemski P, Polkowski W, editors. Zalecenia postępowania diagnostyczno-terapeutycznego w nowotworach złośliwych, vol. 1. Gdańsk: Via Medica; 2013. p. 179-95.

2. Łacko A, Polkowski W, Reguła J, Pałucki J. Rak trzustki i brodawki Vatera. In: Potemski P, Polkowski W, editors. Zalecenia postępowania diagnostyczno-terapeutycznego w nowotworach złośliwych, vol. 1. Gdańsk: Via Medica; 2013, p. 140-50.

3. Altobelli E, Angeletti PM, Latella G. Role of urinary biomarkers in the diagnosis of adenoma and colorectal cancer: A systematic review and meta-analysis. J Cancer 2016;7(14):1984-2004. doi: 10.7150/jca.16244.

4. Berner A, Piekarski J. Rak jelita grubego. In: Kordek R, editor. Onkologia. Podręcznik dla studentów i lekarzy. Gdańsk: Via Medica; 2007. p. 179-84.

5. Zaleśna I, Hartman ML, Czyż M. Znaczenie mutacji BRAF dla progresji czerniaka, raka brodawkowatego tarczycy i raka jelita grubego. Postępy Hig Med Dośw 2016;70:471-88.

6. Francuz T, Czajka-Francuz P, Cisoń-Jurek S, Wojnar J. Rola zapalenia w patogenezie raka jelita grubego. Postępy Hig Med Dośw 2016;70:360-6.

7. Ullman TA, Itzkowitz SH. Intestinal inflammation and cancer. Gastroenterology 2011;140(6):1807-16. doi: 10.1053/j.gastro.2011.01.057.

8. Cubiella J, Salve M, Diaz-Ondina M, Vega P, Alves MT, Iglesias F, et al. Diagnostic accuracy of the faecal immunochemical test for colorectal cancer in symptomatic patients: comparison with NICE and SIGN referral criteria. Colorectal Dis 2014;16(8):0273-82. doi: 10.1111/codi.12569.

9. Castro I, Estevez P, Cubiella J, Hernandez V, Gonzalez-Mao C, Rivera C, et al. Diagnostic performance of fecal immunochemical test and sigmoidoscopy for advanced right-sided colorectal neoplasm. Dig Dis Sci 2015;60(5):142432. doi: 10.1007/s10620-014-3434-6.

10. Iovanescu D, Frandes M, Lungeanu D, Burlea A, Miutescu BP, Miutescu E. Diagnosis reliability of combined flexible sigmoidoscopy and fecalimmunochemical test in colorectal neoplasia screening. Onco Targets Ther 2016;9:6819-28. doi: 10.2147/OTT.S122425.

11. Hosono Y, Goto M, Kobayashi D, Kuribayashi K, Tanaka M, Watanabe N. Diagnostic relevance of autoantibody detection against inhibitors of apoptosis proteins in colon cancer and colon adenoma. Mol Clin Oncol 2015;3(3):595-600. doi: 10.3892/mco.2015.502.

12. Song BP, Jain S, Lin SY, Chen Q, Block TM, Song W, et al. Detection of hypermethylated vimentin in urine of patients with colorectal cancer. J Mol Diagn 2012;14(2):112-9. doi: 10.1016/j.jmoldx.2011.12.003.

13. Nakanishi M, Rosenberg DW. Multifaceted roles od PGE2 in inflammation and cancer. Semin Immunopathol 2013;35(2):123-37. doi: 10.1007/ s00281-012-0342-8.

14. Jeziorski A. Rak trzustki. In: Kordek R, editor. Onkologia. Podręcznik dla studentów i lekarzy. Gdańsk: Via Medica; 2007. p. 197-201.

15. Bockhorn M, Uzunoglu FG, Adham M, Imrie C, Milicevic M, Sandberg AA, et al. Borderline resectable pancreatic cancer: A consensus statement by the International Study Group of Pancreatic Surgery (ISGPS). Surgery 2014;155(6):977-88. doi: 10.1016/j.surg.2014.02.001.

16. Ballehaninna UK, Chemberlain RS. Serum CA 19-9 as a biomarcer of pancreatic cancer - a comprehensive review. Indian J Surg Oncol 2011;2(2):88100. doi: 10.1007/s13193-011-0042-1.

17. Lennon AM, Wolfgang CL, Canto MI, Klein AP, Herman JM, Goggins M, et al. The early detection of pancreatic cancer: what will it take to diagnose 
and treat curable pancreatic neoplasia? Cancer Res 2014;74(13):3381-9. doi: 10.1158/0008-5472.CAN-14-0734.

18. Wu J, Matthaei H, Maitra A, Dal Molin M, Wood LD, Eshleman JR, et al. Recurrent GNAS mutations define an unexpected pathway for pancreatic cyst development. Sci Transl Med 2011;3:92ra66. doi: 10.1126/scitranslmed.3002543.

19. Dranka-Bojarowska D, Lekstan A, Olakowski M, Jabłońska B, Lewiński A, Musiarski $P$, et al. The assessment of serum concentration of adiponectin, leptin and serum carbohydrate antigen-19.9 in patients with pancreatic cancer and chronic pancreatitis. J Physiol Farmacol 2015;66(5): 653-63.

20. Szydło B, Kiczmer P, Świętochowska E, Ostrowska Z. Rola omentyny i chemeryny w zespole metabolicznym i chorobach nowotworowych. Postępy Hig Med Dośw 2016;70:844-9.

21. Karabulut S, Afsar CU, Karabulut M, Alis H, Bozkurt MA, Aydogan F, et al. Clinical significance of serum omentin-1 levels in patients with pancreatic adenocarcinoma. BBA Clin 2016;6:138-42. doi: 10.1016/j.bbacli.2016.10.002.

22. Harada T, Chelala C, Bhakta V, Chaplin T, Caulee K, Baril P, et al. Genomewide DNA copy number analysis in pancreatic cancer using high-density single nucleotide polymorphism arrays. Oncogene 2008;27(13):1951-60. doi: 10.1038/sj.onc.1210832.

23. Sarnecka AK, Zagozda M, Durlik M. An overview of genetic changes and risk od pacreatic ductal adenocarcinoma. J Cancer 2016;7(14):2045-51. doi: 10.7150/jca.15323.
24. Henriksen SD, Madsen PH, Larsen AC, Johansen MB, Drewes AM, Pedersen IS, et al. Cell-free DNA promoter hypermethylation in plasma as a diagnostic marker for pancreatic adenocarcinoma. Clin Epigenetics 2016;8:117. doi: 10.1186/s13148-016-0286-2.

25. Henriksen SD, Madsen PH, Krarup H, Thorlacius-Ussing O. DNA hypermethylation as a blood-based marker for pancreatic cancer. Pancreas 2015;44(7):1036-45. doi: 10.1097/MPA.0000000000000487.

26. Fric P, Skrha J, Sedo A, Zima T, Busek P, Kmochova K, et al. Early detection of pancreatic cancer: impact of high-resolution imaging methods and biomarkers. Eur J Gastroenterol Hepatol 2016;28(12):e33-43. doi: 10.1097/MEG.0000000000000727.

27. Previdi MC, Carotenuto P, Zito D, Pandolfo R, Braconi C. Noncoding RNAs as novel biomarkers in pancreatic cancer: what do we know? Future Oncol 2016;13(5):443-53. doi: 10.2217/fon-2016-0253.

28. Ma X, Kumar M, Choudhury SN, Becker Buscaglia LE, Barker JR, Kanakamedala K, et al. Loss of the miR-21 allele elevates the expression of its target genes and reduces tumorigenesis. Proc Natl Acad Sci U S A 2011;108(25):10144-9. doi: 10.1073/pnas.1103735108.

29. Nagao Y, Hisoaka M, Matsuyama A, Kanemitsu S, Hamada T, Fukuyama T, et al. Association of micro-RNA-21 expression with its targets, PDCD4 and TIMP3, in pancreatic ductal adenocarcinoma. Mod Pathol 2012;25(1):11221. doi: 10.1038/modpathol.2011.142.

30. Liu J, Gao J, Du Y, Li Z, Ren Y, Gu J, et al. Combination of plasma microRNAs with serum CA19-9 for early detection of pancreatic cancer. Int J Cancer 2012;131(3):683-91. doi: 10.1002/ijc.26422. 